\title{
A SURGEON'S PRIVATE PRACTICE IN THE NINETEENTH CENTURY \\ SIR WILLIAM FERGUSSON'S EDINBURGH DAY BOOKS 1832-39, WITH SOME EXTRACTS FROM HIS LONDON DAY BOOKS 1839-77
}

by

\author{
JOHN B. WILSON*
}

Though William Fergusson (1808-77) was born at Prestonpans, his family claimed an impeccable Lochmaben lineage extending back to the time of Robert the Bruce. He attended school in Lochmaben until the age of twelve, when he proceeded to the Royal High School in Edinburgh. On the advice of an uncle who financed his education, Fergusson worked for two years in a lawyer's practice, before choosing a career in medicine. So great an interest and talent did he display in the dissecting room that in 1828 he was appointed first assistant to Dr Robert Knox. Fergusson became a Licentiate of the College of Surgeons of Edinburgh in the same year, and was appointed surgeon to the Edinburgh Royal Dispensary in 1831.

Three articles published in 1977 , one hundred years after his death, have described his successfulcareer in Edinburgh and London. ${ }^{1,2,3}$ Previous to this, a fascinatinginsight had been given into his activities under Robert Knox when extracts from his account book for the Anatomy Class were published by Russell from Melbourne. ${ }^{4}$ The ledger containing these accounts is in the possession of the Royal College of Surgeons of England, and is stored in a large wooden chest along with Fergusson's day books covering his private practice from 1832 till his death in 1877.

The London day books are large diaries, one for each year, but the Edinburgh day book, covering the period 1832-39, is a tall, narrow black ledger in which are noted the date and the name and address of each patient with an occasional comment on the diagnosis. ${ }^{5,6}$ Fergusson summarized each month's work so that the number of patients who consulted him, and the operations he performed, can be easily ascertained. Unfortunately, these notes provide no information on the progress of each patient and no deaths are mentioned, though doubtless they occurred. He must have been an extremely hard worker, for apart from an occasional day or two stolen from his work to visit his wife's home at Spittalhaugh, nearWest Linton, and a month in the spring of 1836 when he visited London and Paris, he seems to have taken little respite from his professional

* John B. Wilson, MD, FRCPE, The Whins, Kinnel Banks, Lochmaben, Dumfriesshire DG11 1TD.

1 Brian Hill, 'A born surgeon', Practitioner, 1977, 219: 907-911.

2 M. R. Ewing, 'Sir William Fergusson', J. R. Coll. Surg. Edinb., 1977, 22: 127-135.

3 J. P. Bennett, 'Sir William Fergusson Bart, 1808-77', Ann. R. Coll. Surg. Eng., 1977, 59: $484-487$.

${ }^{4}$ K. F. Russell, Med. J. Australia, 1967, 2, 875: 1-12.

${ }^{5}$ F. F. Cartwright, 'Young surgeon's day book', The Times, 30 September 1958.

${ }^{6}$ F. F. Cartwright, The development of modern surgery from 1830, London, Barker, 1967, pp. 17-21. 
activities. During his absence in Paris, his practice was looked after by a Mr Stanley.

Fergusson married on 10 October 1833 Miss Helen Ranken, daughter and heiress of Mr William Ranken of Spittalhaugh. They set up house at No. 2 Queen Street in Edinburgh's New Town, two hundred yards from No. 52, the home of his friend and colleague James Young Simpson, Professor of Midwifery at Edinburgh University.

Although Fergusson was a magnificent anatomist and already a surgeon of some repute, the Edinburgh day book shows him largely in the role of a general practitioner, for he performed each month only two or three operations in his private practice. Before the advent of anaesthesia in 1846 and antiseptics in 1865, the number of operations a surgeon could perform was extremely limited and consisted largely of amputation of limbs, digits and breasts, the opening of abscesses, reduction of hernias, and cutting for stones; all operations whose success depended on the speed and manual dexterity of the surgeon as much as on the fortitude of the patient. On one occasion, Fergusson is said to have removed by lateral perineal lithotomy a stone from the bladder of a boy in thirty seconds. ${ }^{7}$ These operations were carried out in the patient's home, a much safer place in which to operate than the hospital in those pre-Lister days.

The first case recorded in the day book was a child of four suffering from croup, who was visited at 62 North Hanover Street at 6 a.m. on 6 May 1832. Fergusson prescribed a mustard poultice, leeches, and tincture of antimony. The child was ill enough to be seen again at 11 a.m., and for a third time that day at 6 p.m.

As with most doctors starting in practice, these must have been worrying days, for the next patient did not appear until 12 May-a woman with dyspepsia, whom Fergusson visited again on two subsequent days. On 16 May, he attended the child of a Mr Horn. On 28 May, he was present at a duel on the Braid Hills between Mr Archibald Marshall and Mr J. M. Ords, when fortunately his surgical services were not required. Then, on 29 May, he attended a Mr McQueen, whose condition required the passage of bougies. Thereafter, the unfortunate Mr McQueen's name occurs frequently in the day book, including forty-four visits in 1837, until March 1838, when bougies were passed on four occasions. His name then disappears from the day book. It seems that poor McQueen's life was not completely ruined by his disability, for he was frequently out when Fergusson called, including one day in May 1835, when he had gone to Musselburgh to play golf.

The steady growth of Fergusson's practice can be observed as more patients consulted him each day. On 16 June 1832, he saw, with Mr Miller, a dancing-master suffering from erisypelas and a sore throat-his first private consultation with a fellowsurgeon. The previous day he had performed his first operation in the house of a patient when he "Slit open prepuce for congenital phymosis". Other operations followed: in September of that year he cut Robert Hunter of Prestonpans for stone; and in January 1834, he removed Mrs Dudgeon's breast. No further visit to Mrs Dudgeon is recorded, so the operation probably proved fatal.

On 14 March 1834, he was called to see a patient at Redford, three miles from the centre of Edinburgh. Fergusson notes that this visit, as well as a subsequent one four days later, was made on horseback, although on a third visit he walked to Redford.

${ }^{7}$ H. Willoughby Lyle, King's and some King's men, Oxford University Press, 1935, p. 107. 
These were the only occasions on which he mentions his mode of transport as he attended his increasingly dispersed practice. His later visits to places outside Edinburgh, such as Wooler, Eddelstone, Kelso, Abbotsford, Haddington, and Penicuik, were probably made on horseback. Though time-consuming, these journeys must have confirmed to Fergusson the steady growth of his reputation.

Presumably, Ferguson would walk from his home in the New Town each day to the Royal Edinburgh Dispensary and to visit his patients in the Old Town and its spreading environments. However, on 24 February 1834, he travelled farther afield to Dunfermline, charging ten shillings for his expenses. Early the next year, he made, with Dr Knox, two visits to Gifford to see the Rev. Dr Sibbald, whose shoulder they set ten weeks after its dislocation; Fergusson's travelling expenses were $£ 3$. Fergusson spent 24 and 25 October 1835 at Spittalhaugh, the first mention of such a trip, for by then he probably considered himself well enough established in his surgical practice to leave it for a few days. Since the turnpike roads of that time were in relatively good condition, he and his wife probably travelled out to West Linton in a horse carriage.

1835 was a busy year for the rising young surgeon. In February, he operated on a patient with an axillary aneurysm. In these cases, the surgeon ligatured the artery proximal, or sometimes distal, to the swelling in the hope that this would induce an improved collateral circulation. Fergusson had reported the tying of a subclavian aneurysm in 1831. After the patient's death five years later, he travelled, in the depths of winter, to Kelso to dissect out the vessels and report the extent of the anastomosis which had developed. ${ }^{8}$

In April and May of 1835, Fergusson operated on three cases of hair-lip and cleft palate, a deformity of special interest to him and one on which he operated using instruments of his own design. In spite of the problems this operation must have presented, Fergusson preferred to operate on a conscious and co-operative patient, even after the advent of general anaesthesia. ${ }^{9}$ Like most surgeons, he enjoyed inventing and modifying instruments, and from his new home at 6 Drummond Place he described an instrument he had modified for use in lithotrity. ${ }^{10}$

Fergusson visited one unfortunate patient, who required to be cut for stone, forty-five times in June 1835. This patient twice required five visits in the course of a day, and forty-four visits during the following month. In August, Fergusson received $£ 100$ as part-payment for these services. Though busy with consultations and making over eighty visits to patients a month, Fergusson performed only two or three operations over the same period. The first case of amputation of the thigh noted in the day book occurs in June, while two days after Christmas, he removed a portion of the upper jaw from a girl in the West Port.

On 7 October 1835, Fergusson records a further important step in his surgical career, his appointment as Assistant Surgeon at the Edinburgh Royal Infirmary.

\footnotetext{
${ }^{8} \mathrm{~W}$. Fergusson, 'Account of the dissection of a patient in whom the subclavian artery had been tied for axillary aneurism', Lond. Edinb. mthly J. med. Sci., 1841, 9: 617-627.

${ }_{9}$ Douglas Guthrie, $A$ history of medicine, London, Nelson, 1945, p. 311.

${ }^{10}$ W. Fergusson, 'On lithotrity, with a description of the instrument used', Edinb. med. surg. J., 1835, 44: $80-85$.
} 


\section{John B. Wilson}

The day book continues through 1836 and 1837, cataloguing an increasing work load. In March 1837, he consulted with Sir Charles Bell, one of Edinburgh's foremost surgeons; then two days later, he extracted, by means of tracheotomy, a plum stone from the trachea of a girl of seven from Kelso, the stone having been present for three months and six days. In June, he amputated the shoulder of a man injured on the railway; and in August, he attended a case of cut-throat in Hamilton. In September, he removed the testicle of a boy of nineteen because of a fungus infection involving the scrotum, and on the day before Christmas, greatly daring, he opened a knee joint and removed a fragment of loose cartilage.

On 1 May 1838, Fergusson notes in the day book another milestone in his surgical career: "Commenced to cut as Junior Surgeon to the Royal Infirmary Mr. Lizars having gone off. Mr. Watson having succeeded and I having gone with Mr. Watson to Wards 1 and 4." By this time, he was able to supplement his income, not that this was really necessary, by taking apprentices. He had again moved house, this time to 22 Albany Street, presumably because of his growing family and surgical practice. Fergusson's reputation was now at its height, and he was said to have shared with Syme, with whom he was not on good terms, ${ }^{11}$ the best surgical practice in Scotland.

\section{THE LONDON DAY BOOKS}

The Edinburgh day book ends on 10 January 1839. Thereafter, Fergusson took up his appointment as Professor of Surgery at the newly opened King's College Hospital in London, where he continued to keep notes of his private practice until his death in February 1877. The volume of work detailed in these diaries, representing only his private practice, is truly immense. Until the last few years of his life, he was seeing patients on Saturdays, Sundays, and even on Christmas Day! Fergusson's only break from work came each autumn, when he spent the month of September at Spittalhaugh. His wife died in 1861, five years before her husband became Sir William Fergusson, Baronet of Spittalhaugh.

Fergusson's move to London coincided with the advent of the steam locomotive and the railway, so that his yearly visits to Spittalhaugh were easily and comfortably made, while he could visit by train patients who resided within a reasonable distance of London. His day book records that on the afternoon of 2 January 1876 , he travelled to Brighton by the 1.16 afternoon train to visit the Baroness de Rothschild. On 26 February the same year, he travelled to Oxford by special train to see a student with rheumatism, for this he received a fee of one hundred guineas. A consultation usually cost only one or two guineas. His local journeys about Dickensian London were made in a smart, bright yellow coach, known, irreverently, to his students as the "Mustard Pot"! Behind stood two postilions, and between the rear wheels of this equipage ran two specially-trained Dalmatians, as much for the protection of the carriage and its occupants as for their stylish appearance.

In 1855, Fergusson was appointed Surgeon Extraordinary to the Queen, and in 1867 Sergeant Surgeon, though his professional services were never required at the palace. Each year, the amount he received for this appointment was entered with considerable

${ }^{11}$ J. B. Wilson, 'Fergusson and Syme of Edinburgh 1838', J. R. Coll. Surg. Edinb., 1986, 31: 372-374. 


\section{A surgeon's private practice in the nineteenth century}

pride in his day book along with his other fees. In 1876, these payments amounted to $£ 6779$ 12s. $3 d$.:

$\begin{array}{lr}\text { Private fees } & £ 57419 s .0 d \text {. } \\ \text { Salary, King's College } & £ 9680 s .0 d \text {. } \\ \text { Sergeant Surgeon } & £ 703 s .3 d .\end{array}$

In failing health, Fergusson spent three months of 1876 in bed, with Dr Johnston and Sir George Burrows in attendance. "Stomach, liver, lungs, heart, kidneys and bladder all seemed wrong", he wrote. However, after a few weeks convalescing with his family at Spittalhaugh, he reported in his day book that the dropsy was less and he could walk three to four miles. Though Fergusson returned to work in London, he saw only a few patients each day, one of the last being the Baron de Stein, who consulted him on account of his brother the Viscount de Stein's mortified limb. The last entry in the day book, on 27 January 1877, records the Viscount's death.

Such was Fergusson's reputation that till the last his opinion was sought on all manner of ailments, not necessarily surgical. In one of the last entries, on 15 January 1877 , a grandmother brought her grandson for consultation, for "The boy when he begins to read takes to yawning". Fergusson must have realized that a large functional element was present, for he notes, "He is well up with his school work, no complaints about him otherwise. Has a brother two years older and he has been kept by his mother up to similar work."

William Fergusson was a product of his time- quick, deft, and bold, with a detailed knowledge of anatomy on which to build his surgical experience. One surgical historian wrote: "Fergusson was the last and perhaps the greatest of that early nineteenth century school of surgeons, who relied for their success upon their own technical skill and knowledge of anatomy."12 Obviously, Ferguson fully deserved the epitaph bestowed upon him by Sir James Paget, who described him as "The great master of his craft, the greatest practical surgeon of our time". ${ }^{13}$ Whilst the Lancet wrote, "Few men equalled and probably none surpassed him as an operator". ${ }^{4}$

\section{ACKNOWLEDGEMENT}

I thank the Librarian of the Royal College of Surgeons of England for the opportunity to examine Fergusson's day books.

${ }^{12}$ Cartwright, op. cit., note 6 above, p. 41.

${ }^{13}$ A. Miles, The Edinburgh school of surgery before Lister, London, A. C. Black, 1918, p. 137.

14 Obituary, Lancet, 1877, i: 258. 